\title{
O processo de Estruturação da Rede de Serviços Turísticos em Canoa Quebrada (Aracati - Ceará - Brasil) e os Principais Impactos Provocados Pelo Turismo no Território
}

\author{
Conceição Malveira Diógenes ${ }^{a}$ \\ Pedro de Alcântara Bittencourt César ${ }^{\mathrm{b}}$ \\ Norberto Nuno Pinto dos Santos ${ }^{c}$
}

\section{Resumo}

Neste artigo, a partir da escala local de Canoa Quebrada (litoral leste do Ceará/Brasil), como parte e fragmento do município de Aracati, estudaram-se algumas transformações físico-territoriais e a relação com os mercados mundiais e globais. Assim, objetivou-se realizar um levantamento histórico da estruturação da rede de serviços turísticos e analisar os principais impactos provocados pelo turismo no território. Como procedimento metodológico aplicou-se questionários aos prestadores de serviços turísticos em uma amostra censitária, e a observação direta participativa. Somam-se ainda entrevistas semiestruturadas com atores representativos do setor, conselhos, associações, instituições de ensino e poder público. Canoa Quebrada, um dos principais destinos turísticos de Ceará, classifica-se como destino indutor da atividade. Aracati possui um rico patrimônio material e imaterial que não se integra efetivamente aos roteiros turísticos comercializados de forma massificada. A velocidade e a dinamicidade com que o fluxo turístico se desenvolveu acarretaram inúmeras transformações físico-territoriais na pequena vila de pescadores, conforme constatado na pesquisa. As transformações vindouras, a construção e a operação do Aeroporto Regional de Aracati, ainda acarretarão inúmeras outras transformações. Este artigo aponta para a necessidade de um planejamento adequado da atividade turística, para a descentralização e a desconcentração das atividades planejadas, para a realização de estudos de capacidade de carga, bem como para um maior envolvimento dos atores locais no processo de gestão do destino. Percebe-se ainda uma clara necessidade de desenvolvimento de pesquisas cientificas sobre impactos econômicos, ambientais, políticoinstitucionais e culturais na região.

Palavras-chave: Turismo; Apropriação do território; Território turístico; Impactos; Redes.

\footnotetext{
Abstract

The Process of Structuring the Tourist Services Network in Canoa Quebrada (Aracati - Ceará - Brazil) and the Main Impacts Caused by Tourism in the Territory In this article, from the local scale of Canoa Quebrada (eastern coast of Ceará/Brazil), as part and fragment of Aracati municipality, it was studied some physical-territorial

a. Pós-doutora em Turismo e Geografia pela Universidade de Coimbra. Docente de Tecnológico em Hotelaria, Técnico em Guia e Eventos no Instituto Federal do Ceará, Aracati, Ceará, Brasil. E-mail: conceicaomdh@gmail.com

b. Pós-doutorando em História pela Universidade de Caxias do Sul. Docente de Programa de PósGraduação em Turismo e Hospitalidade da Universidade de Caxias do Sul. Caxias do Sul, Rio Grande do Sul, Brasil. E-mail: pabcesar@ucs.br

c. Doutor em Geografia Humana pela Universidade de Coimbra. Docente de licenciatura de Turismo, Território e Patrimónios; de mestrado em Turismo, Território e Patrimónios; e doutorado em e Turismo, Património e Território na Universidade de Coimbra. Coimbra, Portugal. E-mail: norgeo@ci.uc.pt
} 
transformations and the relation with world and global markets. Thus, it aimed to to carry out a historical survey of the structuring of the tourist services network and to analyze the main impacts caused by tourism in the territory. As a methodological procedure, it accomplished the application of questionnaires to tourism service providers in a census sample, and direct participatory observation. There were also semi-structured interviews with actors representing the sector, councils, associations, educational institutions and public authorities. Canoa Quebrada, one of the main tourist destinations in Ceará, is classified as an activity-inducing destination. Aracati has a rich tangible and intangible heritage that that does not integrate effectively with massively marketed tourist routes. The speed and dynamism with which the tourist flow developed led to numerous physical-territorial transformations in the small fishing village, as found in the research. The upcoming transformations, the construction and operation of the Aracati Regional Airport, will still lead to countless other transformations. This article points to the need for an adequate planning of the tourist activity, for the decentralization and the deconcentration of the planned activities, for carrying out load capacity studies, as well as for greater involvement of local actors in the destination management process. There is also a clear need for the development of scientific research on economic, environmental, political-institutional and cultural impacts in the region.

Keywords: Tourism; Appropriation of territory; Touristic territory; Impacts; Network.

\section{Resumen}

El Proceso de Estructuración de la Red de Servicios Turísticos en Canoa Quebrada (Aracati - Ceará - Brasil) y los Principales Impactos Provocados por el Turismo en el Territorio

En este artículo, de la escala local de Canoa Quebrada (costa este de Ceará/Brasil), como parte y fragmento del municipio de Aracati, se estudiaron algunas transformaciones físico-territoriales y la relación con los mercados mundiales y globales. Así, El objetivo fue realizar un relevamiento histórico de la estructuración de la red de servicios turísticos y analizar los principales impactos provocados por el turismo en el territorio. Como procedimiento metodológico, ocurrió la aplicación de cuestionarios a los prestadores de servicios turísticos, en una muestra censal, y la observación participativa directa. También hay entrevistas semiestructuradas con actores representantes del sector, ayuntamientos, asociaciones, instituciones educativas y autoridades públicas. Canoa Quebrada, uno de los principales destinos turísticos de Ceará, está clasificado como un destino inductor de actividad. Aracari cuenta con un rico patrimonio material e inmaterial que no que no se integra eficazmente con las rutas turísticas masificadas. La velocidad y el dinamismo con que se desarrolló el flujo turístico provoco numerosas transformaciones físicoterritoriales en el pequeño pueblo de pescadores, como se encuentra en la investigación. Las transformaciones por venir, la construcción y operación del Aeropuerto Regional de Aracati, aún conducirán a innumerables otras transformaciones. Este artículo apunta para la necesidad de una adecuada planificación de la actividad turística, para la descentralización y desconcentración de las actividades planificadas, para la realización de estudios de capacidad de carga, así como para una mayor implicación de los actores locales en el proceso de gestión del destino. También existe una clara necesidad de desarrollo de investigación científica sobre impactos económicos, ambientales, políticoinstitucionales y culturales en la región.

Palabras clave: Turismo; Apropiación de territorio; Territorio turístico; Impactos; Red. 


\section{INTRODUÇÃO}

Os estudos sobre o turismo nos últimos anos parecem buscar novas abordagens e novos olhares sobre o mesmo. Alguns autores defendem a ideia do surgimento de um pós-turismo, uma vez que o fenômeno passa por transformações radicais a partir do final do século XX (Molina, 2003; Brazo \& Fonseca Filho, 2018). Neste artigo, busca-se realizar um levantamento histórico da estruturação da rede de serviços turísticos e analisar os principais impactos provocados pelo turismo no território

$\mathrm{Na}$ tentativa de compreender essas transformações, associam-se neste artigo os conhecimentos da área do turismo aos estudos sócio-espaciais ${ }^{1}$, em especial à abordagem de redes trabalhada pelo sociólogo Manuel Castells em sua obra Sociedade em Redes (1999), e pelos geógrafos Milton (2014), em A Natureza do Espaço, e Roberto Lobato Corrêa (2001) na obra Trajetórias Geográficas.

Inicialmente, os deslocamentos faziam parte do cotidiano de vida dos seres humanos nômades. Segundo Boullón (2002, p. 29), “[...] na medida em que a superfície da Terra foi sendo ocupada e explorada, as atividades produtivas tradicionais e outras criadas pelo homem aumentaram seu grau de especialização e foram dominando e caracterizando aqueles lugares em que se instalaram e progrediram.".

Essa ocupação, descrita por Boullón, deixa marcas no território e cria características específicas em cada local. Especificamente no turismo, Molina (2003) defende a existência de três fases distintas de desenvolvimento: o pré-turismo, que tem como representante as viagens do Gran Tour; o turismo industrial, subdividido em industrial primitivo e industrial maduro; e o pós-turismo surgindo a partir do final do século XX. Todavia, importa referir que a explicitação turística neste texto é significativamente diferente, por vezes oposta, à que Molina (2003) defende com o pós-turismo (p. 53-55), já que se assume, aqui, o contato do visitante com as pessoas das comunidades locais. Sabendo-se da presença de uma encenação constante, procura-se que ela seja suportada pelo autêntico, tanto natural, quanto cultural, e não como simulacro associado ao consumo (Baudrillard, 1970), não-lugar (Marc Augé, 1994) ou desterritorialização (Haesbaert, 1994, 1997, 2001a, 2001b, 2002a, 2002b, 2004).

Atualmente, os fluxos gerados pelo turismo e pelas viagens também podem fazer parte de hábitos cotidianos; as motivações para esses deslocamentos é que foram se transformando ao longo do tempo. 0 fluxo de turistas, esse ir e vir, possibilita a constituição de relações, estabelece percursos e lança olhares diferenciados sobre os lugares. Com o passar dos anos, as pessoas se apropriaram de determinados territórios e criaram os espaços urbanos com especializações produtivas, mas o desejo de conhecer o novo e o diferente continuou pulsando nos seres humanos. Assim como os homens que viviam na caverna

1. De acordo com Carlos, Souza e Spoosito (2018, p.17) deve-se ter cuidado para não se cair em uma interpretação estreita do tremo socio-espacial/socioespacial. Diferentemente do que ocorre com os termos socioeconómico, sociopolítico e sociocultural que são termos dicionarizados e em que o social serve para qualificar os termos que seguem. 0 socio-espacial deve ser uma composição de termos, havendo a intenção de composição e complementação, tal como ocorre com austro-húngaro e dólico-louro. Para tanto os autores reforçam que ambos os termos são considerados corretos e devem ser aceitos. Neste trabalho decidimos utilizar o termo com o uso de hífen para mantermos a ideia de composição. 
imaginada por Platão, os quais viam apenas sombras do mundo e queriam desvendar o que havia fora, os seres pós-modernos desejam conhecer e reconhecer lugares diferentes dos que compõem sua origem. A necessidade de movimento, a inquietação e o desassossego parecem continuar fazendo parte da natureza humana.

Este trabalho divide-se em cinco partes: a parte introdutória descreve a temática. Na segunda parte, o leitor é apresentado ao recorte territorial estudado, a Vila de Canoa Quebrada (Aracati, Ceará, Brasil). A terceira parte descreve o percurso metodológico da pesquisa, os caminhos trilhados. Na quarta parte apresentam-se os principais conceitos estudados tais como redes e impactos sócio-espaciais e descreve-se o processo histórico de estruturação da rede de serviços turísticos na escala local. A última parte discorre sobres os impactos sócio-espaciais da estruturação da rede e aponta algumas reflexões possíveis.

\section{RECORTE TERRITORIAL}

A praia de Canoa Quebrada localiza-se a 12 quilômetros da sede do município de Aracati e a 162 quilômetros da capital do estado do Ceará, no nordeste brasileiro, e possui como símbolo uma lua em fase crescente e uma estrela, como representado na Figura 1. 0 seu processo de desenvolvimento se assemelha significativamente ao de outras praias nordestinas, ou seja, uma pequena vila de pescadores que é "descoberta" por turistas e se diferencia em muitos outros aspectos das grandes cidades litorâneas desta região do país como Salvador (BA), Recife (PE) e Fortaleza (CE).

Figura 1 - Mapa de localização da Vila de Canoa Quebrada - Ceará - Brasil

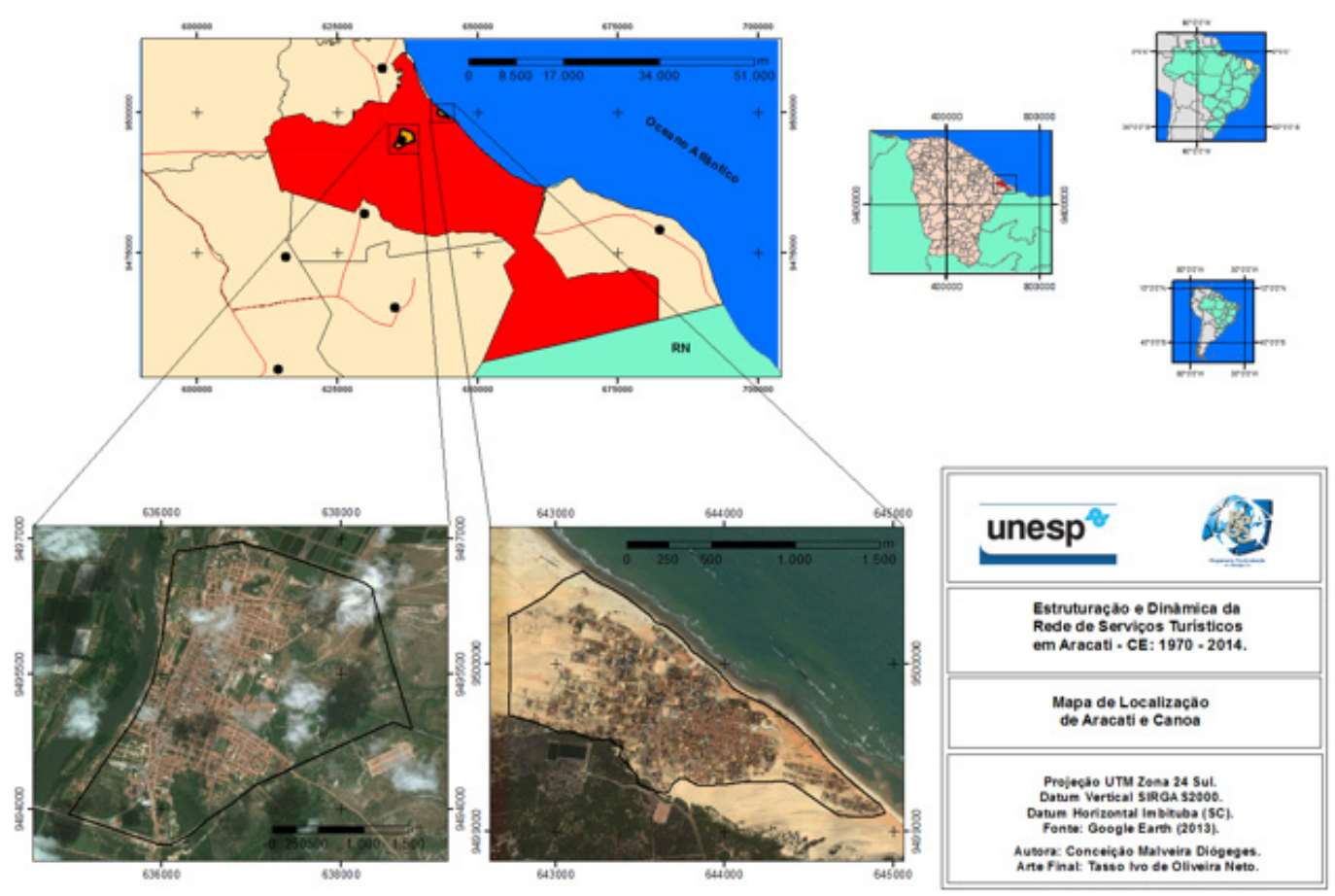

Fonte - Resultado da pesquisa. 
De acordo com pesquisas do antropólogo Alexandre Vale, apresentadas no vídeo "Canoa verso rabiscado na areia" (2015), nos anos de 1960 a pequena vila de pescadores foi cenário para o filme francês Le Grabuge, sendo colocada em evidência.

O professor Regis Azevedo Esmeraldo (2002) afirma que, na década de 1970, surgiram em Canoa Quebrada os primeiros turistas provenientes do movimento hippie e tecnicamente caracterizados, segundo Costa e Santos (2018), como turistas alocêntricos - viajantes desbravadores e aventureiros que buscavam destinos turísticos de natureza "intocada" e que estavam sempre em busca de novos destinos, em constante processo de descoberta e abandono dos locais. Em Canoa Quebrada, esses visitantes eram oriundos do Sul e Sudeste brasileiro e de outros países, principalmente Suíça e França. Alguns deles fixaram residência no local e passaram a investir na atividade turística como forma de permanecer na praia. Iniciavam-se assim as relações mais duradouras entre a população tradicional da vila de pescadores e os estrangeiros que resolveram viver no destino turístico.

O destino Canoa Quebrada é transformado, em março de 1998, em uma unidade de conservação, conforme a Lei Municipal n. 40/1998 (Menezes, Araújo \& Romero, 2010) que cria a APA de Canoa Quebrada como ecossistema costeiro, complexo vegetacional e litorâneo, buscando a preservação e a conservação dos seus recursos ambientais, com vistas à sua própria sobrevivência e à manutenção dos atrativos turísticos.

Em áreas de preservação ambiental, como no caso da Vila de Canoa Quebrada, as preocupações com o desenvolvimento sustentável deveriam ser intrínsecas ao planejamento das atividades econômicas possíveis para o lugar. No caso do turismo de sol e praia, em que o meio ambiente é também meio de produção, espaço de consumo e fator condicionante, essas reflexões tornam-se indispensáveis. 0 conceito de desenvolvimento sustentável é definido no Relatório Brundtland como sendo "[...] atividade que harmoniza o imperativo do crescimento econômico, com a promoção da equidade social e a preservação do patrimônio natural, garantindo assim que as necessidades das atuais gerações sejam atendidas, sem comprometer o atendimento das necessidades das gerações futuras." (CNUMAD, 1991).

Esse conceito de sustentabilidade baseia-se, portanto, sobre três pilares básicos: a eficiência econômica, a prudência ecológica e a justiça social, conforme afirma Rodrigues (2003). Esses três pilares, no entanto, envolvem dimensões capazes de influenciar o processo de desenvolvimento. Rodrigues (2003) propõe uma série de dimensões da sustentabilidade que devem ser levadas em consideração para o planejamento e desenvolvimento de um destino turístico, são elas: espacial, demográfica, política, econômica, social, cultural, institucional, jurídica, planetária e ecológica.

Essas dimensões deveriam ser preocupações constantes em destinos turísticos que se desenvolvem em áreas de preservação ambiental. Durante a realização desta pesquisa não foram encontrados instrumentos de planejamento e de gestão da atividade em Aracati. Sabe-se que o município elaborou um plano de manejo para a APA de Canoa Quebrada, mas o documento não foi sancionado pela Câmara Municipal e tampouco divulgado. 


\section{CAMINHOS TRILHADOS}

Assim como a maioria dos processos de pesquisa, este iniciou-se com um levantamento teórico da área. Nessa etapa, observou-se que diversos estudos tratando do turismo foram realizados em Canoa Quebrada, alguns discutindo o processo de desenvolvimento do destino e outros a formação de um arranjo produtivo na vila. 0 levantamento bibliográfico e documental contemplou trabalhos publicados em livros, e nos principais repositórios de teses e dissertações, onde foram identificados oito trabalhos acadêmicos sobre Aracati. No entanto, foram encontrados apenas dois artigos científicos no Google Acadêmico sobre o recorte territorial estudado. O levantamento foi realizado em 2016 e buscou trabalhos publicados entre os anos de 1995 a 2015. Já os documentos foram levantados presencialmente na Secretaria Estadual do Turismo do Ceará, na Secretaria Municipal de Turismo e Cultura de Aracati, no Grupo Gestor do Destino e no SEBRAE-CE (Serviço de Apoio às Micros e Pequenas Empresas).

Neste trabalho, que constitui parte da pesquisa de doutorado de um dos autores, o objetivo foi realizar um levantamento histórico da estruturação da rede de serviços turísticos em Canoa Quebrada e analisar os principais impactos provocados pelo turismo no território. Os interesses voltam-se para o fenômeno turístico e as transformações decorrentes da estruturação de sua rede.

Após um levantamento cuidadoso dos estudos pré-existentes e da revisão bibliográfica, realizou-se no município de Aquiraz, também no litoral leste cearense, a aplicação de pré-teste com a rede local. Foram aplicados dez formulários com os gestores dos meios de hospedagem. Nessa oportunidade, identificaram-se pontos em que poderia haver dúvidas, e obtiveram-se algumas orientações sobre novas questões a serem levantadas e tempo de aplicação.

No segundo semestre do ano de 2015, através de um levantamento censitário, foram aplicados 91 formulários estruturados com os gestores dos negócios que prestavam serviços turísticos. 0 objetivo era traçar o perfil dos empresários, caracterizar os negócios locais, identificar as dinâmicas de relações existentes em Canoa Quebrada/CE e indagar sobre os efeitos da estruturação da rede. Na aplicação dos formulários foi possível observar sinais de uma grande rotatividade, tanto dos prestadores de serviços de hospedagem como dos serviços de alimentação. Perceberam-se evidências de que os pontos eram constantemente transferidos. Em alguns casos, isso não implicava em mudança do nome, apenas de gestão, mas em outros observou-se a mudança também no nome da empresa. As listagens de empreendimentos turísticos rapidamente tornam-se desatualizadas dada essa dinâmica local, o que compromete a mensuração exata dos prestadores de serviços, mesmo através dos dados oficiais. As entrevistas semiestruturadas foram aplicadas com representantes da Associação do Barraqueiros, da Associação Comunitária, com Técnicos da Secretaria Municipal de Turismo, e com Coordenadores dos cursos técnicos e superiores da área de turismo (Instituto Federal do Ceará, Escola Profissionalizante e Faculdade Vale do Jaguaribe).

Além da aplicação de formulários, buscou-se realizar uma leitura da realidade do lugar, através da observação direta participante. 0 tempo possibilitou aprofundar a visão da área estudada. Assim, foi possível integrar o espaço para construir um relato das práticas constituídas pelos elementos da rede de serviços 
turísticos, bem como vivenciar o que os membros da comunidade vivenciam no ambiente real onde a rede se estrutura.

A sistematização dos dados utilizou o Statistical Package for the Social Sciences (SPSS) e pode transformar os dados em informações. As informações estatísticas sistematizadas foram somadas às entrevistas semiestruturadas e às observações feitas em campo e analisadas à luz da teoria das redes desenvolvida de forma pioneira por Castells (1999) e Corrêa (2001).

\section{A GLOBALIzAÇÃo e A FORMAÇÃo dAS REDES de TURISMO}

Haesbaert e Limonad (1999) afirmam que incialmente quando pensava-se em globalização, imaginava-se um processo de "homogeneização sócio-cultural, econômica e espacial" (p. 7). Essa homogeneização levaria à "dissolução das identidades locais, tanto econômicas quanto políticas e culturais, em uma única lógica, e que culminaria em um espaço global despersonalizado." (p. 7). Essa ideia se aproxima do que imaginava Molina (2003) em sua obra sobre o pós-turismo. No entanto, Haesbaert e Limonad (1999) ressaltam que essa homogeneização não ocorreu de fato, tendo havido uma expansão do capitalismo e da sociedade do consumo, o que os autores tratam como:

[...] uma forma mais avançada e complexa da internacionalização, implicando em um certo grau de integração funcional entre as atividades econômicas dispersas em escala planetária e a um crescimento cada vez mais pronunciado dos fluxos do capital financeiro de caráter volátil ou fictício. (p. 9)

0 desenvolvimento das tecnologias fez com que o mundo se conectasse em uma velocidade maior. Grandes acontecimentos podem ser assistidos de todos os continentes - Harvey (2012) cita exemplos emblemáticos como as Copas do Mundo, a queda do Muro de Berlim e mesmo as cúpulas politicas mundiais. 0 autor explica que "a imagem dos lugares e espaços se torna tão aberta à produção e ao uso efémero quanto qualquer outra“ (Harvey, 2012, p. 264). 0 autor é enfático ao afirmar que a quebra das barreiras espaciais não significa necessariamente $o$ decréscimo da significação do espaço, havendo evidências para o caminho oposto e a exploração das diferenciações.

No Brasil existe uma forte tradição sobre as redes urbanas com foco nos reflexos para a organização do espaço regional. Neste campo destacam-se os estudos de Milton Santos (2008) e de Roberto Lobato Corrêa (2001). Esses estudos focam suas análises nas questões relacionadas a aglomeração, acessibilidade, interação espacial, hierarquia e competitividades. No turismo é inegável a influência de estudiosos como Fratucci (2009) e Fávero (2012).

Neste sentido Fratucci (2009) explica que:

A sociedade contemporânea, para alguns, dita pós-moderna, experiência o 'viver em redes', em que os territórios e as territorialidades passam a ser concebidos e caracterizados pelo movimento, pela fluidez e pelas interconexões, portanto, pelas redes. Assim como outras atividades econômicas contemporâneas, o turismo concretiza-se pela ação, pela articulação e pela interconexão dos seus diversos agentes 
produtores no tempo e no espaço. Isto nos abre a possibilidade de pensarmos o turismo e, em especial a sua dimensão espacial, a partir da perspectiva das redes e dos territórios-rede, descontínuos e sobrepostos (p. 395).

Nesta mesma perspectiva Castells (1999), pioneiro nos estudos sobre redes, afirma ainda que redes são estruturas abertas, baseadas na inovação e na globalização. Já Fratucci (2009) explica que:

Com base no comportamento e nas ações dos diversos agentes produtores do turismo, o espaço turistificado organiza-se a partir de pontos/nós (destinos turísticos) articulados e interligados entre si e com outros pontos/nós (centros emissores), estabelecendo tessituras hierarquizadas, que variam de intensidade e de escala, de acordo com o tipo e o modo do turismo estabelecido (p. 396).

A partir das perspectivas apresentadas analisa-se o processo histórico de formação da rede de serviços turísticos de Canoa Quebrada - Aracati- Ceará.

\section{PROCESSO HISTÓRICO DA ESTRUTURAÇÃO DA REDE DE SERVIÇOS TURÍSTICOS DE ARACATI / CANOA QUEBRADA (CEARÁ - BRASIL)²}

Atualmente a organização da rede de turismo local formada em Aracati, apresenta-se conforme demonstrado na Figura 2, em que os elementos e nós que compõem a rede local de turismo são identificados e se evidencia o nível de articulação e integração com outras escalas, especialmente a nacional e a internacional.

Figura 2 - Elementos e nós da rede de serviços turisticos

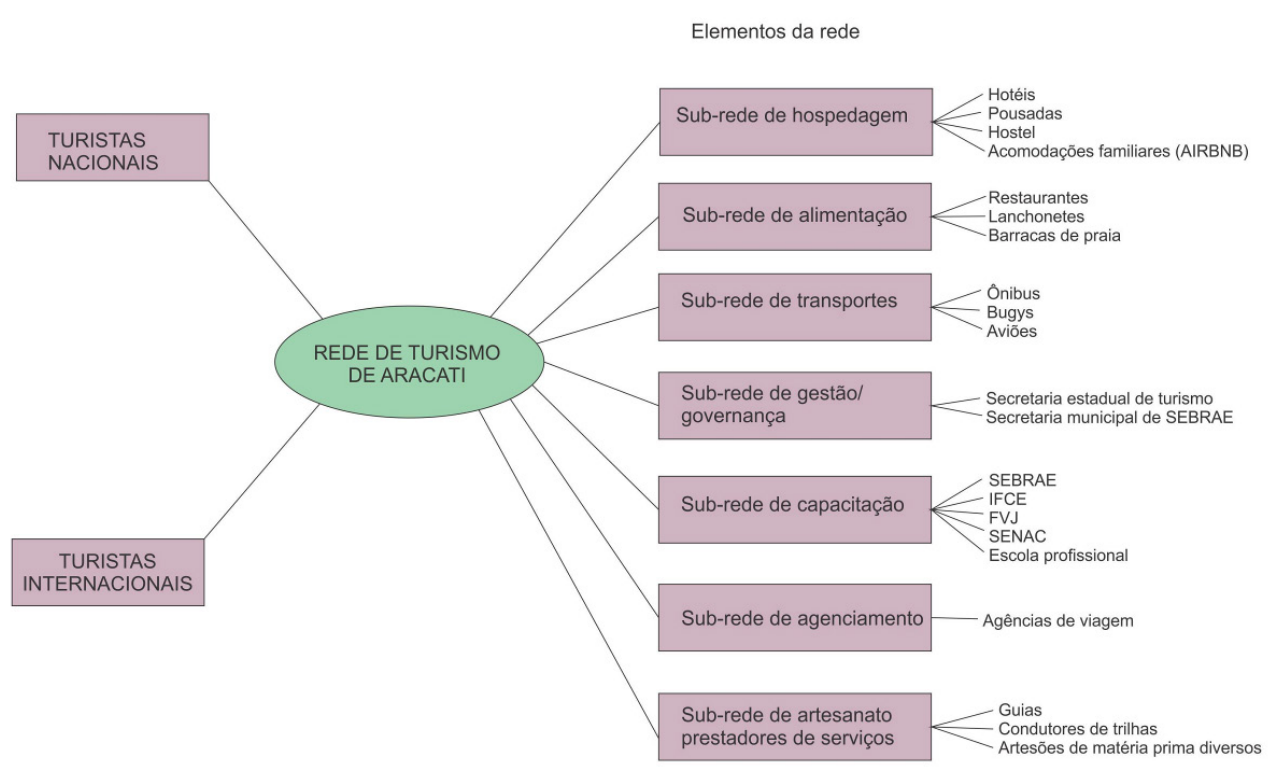

Fonte - Resultado da pesquisa.

2. Evidencia-se no texto os principais impactos da atividade turística em Canoa Quebrada destacados no artigo. 
No entanto, a formação da rede de serviços turísticos deu-se através de um processo histórico em que, ao longo desse caminho, foram sendo gerados inúmeros efeitos sóocio-espaciais que serão descritos.

A construção do que Dollfus (1991) intitula de identidade e personalidade própria dos espaços, e a ressignificação da Praia de Canoa Quebrada a partir do desenvolvimento da atividade do turismo, permitiram a construção de uma imagem diferenciada para o destino turístico no estado do Ceará.

A sede do município de Aracati apresenta um significativo patrimônio histórico, tombado pelo Instituto de Patrimônio Histórico e Artístico - IPHAN desde 2001, apresentado no Guia de Bens Tombados (Diógenes \& Duarte Júnior, 2006). Suas 2.500 edificações construídas a partir de 1747 representam um verdadeiro palimpsesto formado em seu território, sendo que, durante muitos anos, essa cidade dominou o cenário econômico e político do Vale do Jaguaribe (Diógenes \& Duarte Júnior, 2006). Assim, é imprescindível contextualizar os fluxos criados através do Rio Jaguaribe com todo o seu vale. Esta relação criou conexões indissolúveis entre o litoral e o sertão. 0 litoral de Aracati e a foz do Rio Jaguaribe representaram, no período colonial, a porta e o porto do Ceará. Nos dias atuais, Aracati ainda é o local de balneabilidade litorânea dos jaguaribanos, sendo muitas vezes a primeira imagem do mar experienciada por eles.

Nas primeiras fases de opulência econômica do município, a praia de Canoa Quebrada era praticamente desconhecida, não sofrendo influências dessa condição. A Vila era um fragmento isolado no território de Aracati.

No cenário atual, esses fragmentos do espaço, Aracati sede e Canoa Quebrada, que no passado não possuíam muitos vínculos, passaram a ser lugares constituídos de inúmeras relações sociais, sendo Canoa Quebrada a área central para o desenvolvimento da atividade turística, o destino turístico propriamente dito. No entanto, é na sede do município em que estão localizadas as edificações que compõe o patrimônio material descrito, representantes da evolução histórico e econômica do estado do Ceará. Harvey (2012) destaca, no entanto, que:

A ironia é que a tradição é agora preservada com frequência ao ser mercadificada e comercializada como tal. A busca de raízes termina, na pior das hipóteses, sendo produzida e vendida como imagem, como simulacro ou pastiche (comunidades de imitações construídas para evocar imagens de algum passado agradável, o tecido de comunidades operárias tradicionais apropriado por uma pequena nobreza urbana)(p. 273).

Na sede de Aracati, a população, de modo geral, parece que ainda não se apercebeu da relevância de seu patrimônio material, não valorizando os bens tombados como parte de sua identidade. Observam-se, inclusive, tentativas dos proprietários dos imóveis em burlar as regras do IPHAN, derrubando casarões inteiros durante a noite. 0 turismo que, na pior das hipóteses, transformaria esse patrimônio em mercadoria, ainda não se apropriou dele e não gerou fluxos significativos para a sede do município, ou seja, nem simulacro nem pastiche. 
Figura 3 - Registros do patrimônio material de Aracati: costumes e tradições
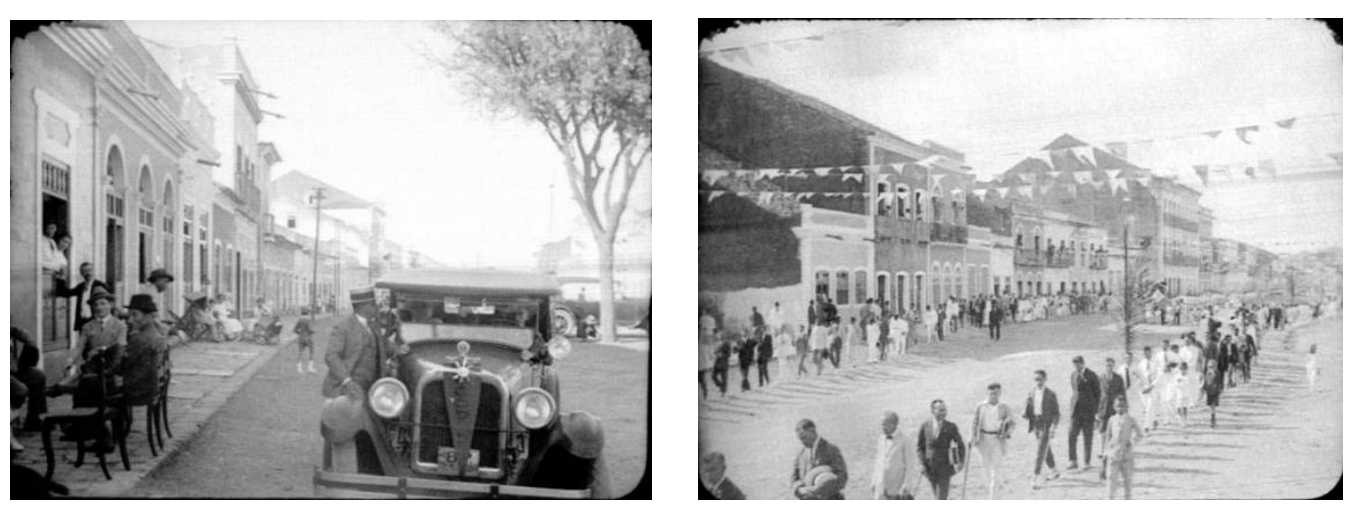

Fonte - Museu da Imagem e do Som, Acervo Nirez, sem data.

Uma das consequências mais evidentes dos avanços tecnológicos e da globalização é a democratização das viagens (Urry, 2001), priorização do lazer (Lipovrtsky, 2007) e o aumento da dinâmica dos fluxos turísticos que chegam aos lugares mais longínquos, descentralizados dos grandes centros urbanos, invadindo áreas preservadas, os denominados de lugares paradisíacos. De acordo com Lipovrtsky (2007, p. 53) na sociedade do hiperconsumo, as atividades de lazer já ocupam $30 \%$ do tempo desperto dos jovens, sendo as coisas mais consumidas: ficção, jogos, música e viagens.

Esse novo fluxo de visitantes provenientes de outros locais vai, gradualmente, modificando a realidade encontrada. A Praia de Canoa Quebrada dos dias atuais não poderia ser comparada à que foi descoberta pelo visitante ainda entre os anos de 1960 e 1970 . Além das mudanças ocorridas naturalmente pela passagem do tempo, ocorreram mudanças associadas ao desenvolvimento do turismo como atividade econômica.

É muito comum constatar, a partir do desenvolvimento da atividade turística, um declínio, ou mesmo o desaparecimento de atividades tradicionais, percebendo-se um aparente desejo de mudança de vida nas comunidades tradicionais. No município de Aracati, observa-se que essas atividades, as quais denomina-se de arcaicas, tais como agricultura, pecuária de subsistência, pesca e produção artesanal, continuam resistindo. Não ocorreu uma absorção de toda a mão de obra local pela atividade turística e nem mesmo uma migração integral desses profissionais para o setor. Outras atividades econômicas também despontaram em Aracati, tais como o cultivo de camarão em cativeiro. 0 município, que não chegou a apresentar aspectos de uma industrialização, passou do setor primário ao terciário. Canoa Quebrada que era essencialmente habitada por pescadores e suas famílias, passou a ser habitada também pelos empreendedores do setor do turismo, criando fragmentos sócio-territoriais, definidos muitas vezes como guetos, entre estes grupos (Diógenes, 2016).

Borzacchiello, Cavalcante e Dantas (2007) ressaltam, no entanto, que a atividade pesqueira é parte da história do povo cearense, sendo os índios que viviam no litoral do Ceará retratados como exímios pescadores. Nesta condição, a sociedade indígena não era essencialmente marítima ou mesmo completamente coletora e interiorana. Porém, comumente, associa-se que os homens, os quais viviam do mar, estavam afastados das intempéries do sertão nordestino, tais como 
a seca e a fome. As praias foram, durante muitos anos, área de domínio da atividade pesqueira; mas atualmente, essa atividade divide espaços com os veranistas, os turistas, os barraqueiros, os bugueiros e os ambulantes, as quais, segundo Borzacchiello, Cavalcante e Dantas (2007), representam as novas práticas litorâneas. Nota-se que esse mosaico sócio-espacial retrata contradições entre complementações e disputas territoriais e de interesses econômicos.

Muitos pescadores passaram a fazer passeios de jangada com os turistas, sem deixar, no entanto, a atividade pesqueira. Vistos como produtos exóticos, cria-se, ainda adotando a ideia Borzacchiello, Cavalcante e Dantas (2007), um espaço de consumo. A transformação observada, nesse caso, não diz respeito exclusivamente ao local e às novas formas de ocupação e uso, mas também ao próprio instrumento de trabalho do pescador, que passa a ser objeto de consumo nos passeios turísticos. Observa-se que o turismo e a pesca se alternam e, associados com outras atividades tradicionais, ajudam a consolidar a imagem de um lugar, em que o tempo parece obedecer a uma lógica distinta e distante. Embora expostos a influências diversas que podem vir a alterar tudo isto.

Ao capturar a imagem da lua e da estrela nas falésias de Canoa Quebrada, talvez Kako Lima Verde não estivesse ciente do seu papel de intérprete de um momento social: ele impregnava de sentido um fragmento do espaço que, antes, era apenas uma parte de um espaço repleto em valor simbólico, enquanto a sede de Aracati estava propensa a experimentar o que Costa (2015, p. 108) chamou de "ultravalorização econômica dos lugares memória".

No final da década de 1970, como descrito anteriormente, a praia de Canoa Quebrada era uma pequena vila de pescadores que possuía apenas 1.200 moradores e 178 residências; em 2010, a população fixa de Canoa Quebrada era de 4.955 pessoas. Na década de 1970, a quantidade de turistas que visitavam Canoa Quebrada era pouco significativa, a qual era acolhida nas residências dos pescadores da vila. Em 2010, a população flutuante (turistas), em um dia de alta estação, era de aproximadamente 3.360 turistas, segundo dados da Secretaria Estadual de Turismo (Ceará, 2010). 0 aumento do fluxo gerou a estruturação de uma rede de serviços turísticos permitindo receber os visitantes em meios de hospedagem de pequeno e médio porte, e não só nas residências de pescadores.

A existência de uma centralização, no sentido proposto por Corrêa (2001), é inquestionável, uma vez que existe a aglomeração ou a concentração dos elementos prestadores de serviços da rede em Canoa Quebrada e, principalmente, próximo ao mar. No passado, de acordo com os relatos dos entrevistados, as pessoas precisavam sair de Canoa Quebrada em direção à sede para obter trabalho, ou mesmo para resolver questões da vida cotidiana. Após a nova situação que se pode chamar de choque de modernidade, experimentado a partir do turismo, o movimento de fluxos apresenta uma tendência de inversão. Atualmente, as pessoas saem de Aracati e passam a buscar trabalho na antiga vila de pescadores ressignificada, graças a acessibilidade criada para favorecer o fluxo de turistas, mercadorias e trabalhadores.

O custo de vida em Canoa Quebrada, assim como observado em outras destinações, é mais elevado do que na sede do município e, como a distância é relativamente curta, as pessoas optam por viver na sede, conforme afirmado pelos entrevistados. Constata-se também que a sede dispõe de melhor estrutura, de rede bancária, de supermercados, de escolas e hospitais, fazendo com que 
quem resida em Canoa Quebrada, acabe por precisar se deslocar para Aracati. Assim, pode-se afirmar que uma das transformações observadas é a interdependência funcional entre estes fragmentos do espaço.

Sabe-se, no entanto, que "Toda paisagem que reflete uma porção do espaço, ostenta marcas de um passado mais ou menos remoto, apagado ou modificado de maneira desigual, mas sempre presente." (Dollfus, 1991, p. 11). As marcas do passado da sede de Aracati são fáceis de serem observadas, como no caso dos prédios tombados e refuncionalizados, a exemplo do Instituto Museu Jaguaribana.

Figura 4 - Refuncionalização de edificações: de residência a museu
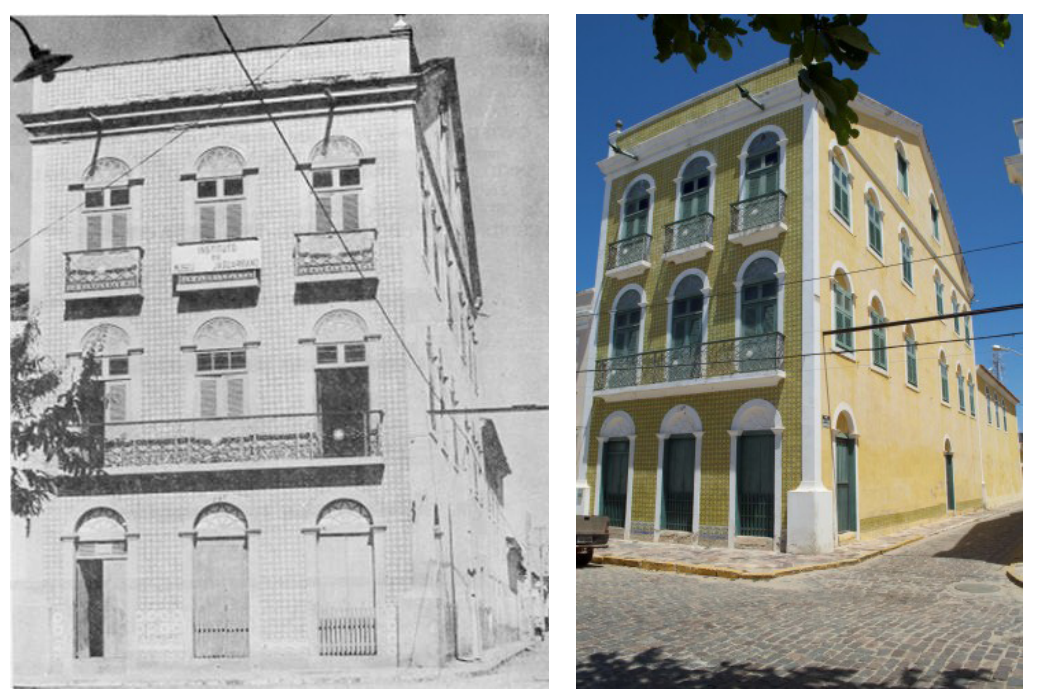

Fonte - Museu da Imagem e do Som, Acervo Nirez (sem data). Acervo dos autores.

Em Canoa Quebrada, é mais fácil perceber as modificações nas formas de ocupação do lugar: os pescadores, que antes residiam próximos ao mar, "cederam" espaço para os meios de hospedagem e barracas de praia, e foram buscar moradia na comunidade do Estevão ou aos pés das dunas, onde se formou uma ocupação mais desordenada. A comunidade do Estevão representa, para muitos de seus membros, um lugar de resistência, havendo uma insubordinação ao "tempo" e à forma de vida de Canoa Quebrada.

As relações constituídas no fragmento de Canoa Quebrada não estão restritas à sede do município; pois elas alcançam inúmeras escalas geográficas, da local, passando para à nacional e global. Observa-se, através das repostas dos entrevistados quanto à origem dos visitantes que circulam pela Vila, pessoas de diversas nacionalidades e de diferentes regiões do Brasil. Essa ampliação das relações faz de Canoa Quebrada um lugar heterogêneo sob muitos aspectos, mas, principalmente, no que diz respeito aos "tempos vividos". Harvey (2012) destaca que "As práticas espaciais materiais se referem aos fluxos, transferências e interações físicas e materiais (p. 201)"; os fluxos de turistas gerariam essas interações entre a cultura dos que ali vivem com a cultura dos que ali visitam.

Atualmente, a vila de Canoa Quebrada, está conectada com o mundo globalizado, e para isso os prestadores de serviços precisam viver sob a égide dos "tempos rápidos" o que contrapõem com os tempos lentos (Santos, 2014). Desse modo, eles apresentam a imagem do destino turístico na internet, constroem 
para ele um significado, a fim de que os clientes em potencial sintam o desejo de consumi-lo. E, nesse mundo virtual, em que centenas de destinos turísticos apresentam sua imagem para os turistas, é preciso vender uma imagem composta de significados para, assim, mobilizar fluxos e dinâmicas. Todavia precisa-se entender a importância da sustentabilidade na relação entre o produto massificado e o produto de pequena oferta ou pequena empresa.

A pesquisa de campo com os prestadores de serviços turísticos aponta que os fatores que motivam os turistas que saem das grandes metrópoles e optam por visitar Canoa Quebrada, para desfrutar dos momentos de lazer, chegam desejosos de "tempos lentos", e da imagem que lhes foi apresentada virtualmente e construída em seu imaginário. Nesse sentido, a priori, a vila de Canoa apresenta "tempos lentos" e "tempos rápidos", não havendo um comportamento uno. A conectividade não inclui todos, assim como não deixa todos desconectados ou excluídos; como visto na pesquisa de campo, existem prestadores de serviços que não possuem computadores ou conexão com a rede mundial de computadores, e permanecem isolados em um mundo que parece cada dia mais conectado.

De acordo com Middleton e Clarke (2002, p. 508) os novos consumidores estão mais preocupados e conscientes com relação ao meio ambiente, incluindo as questões sociais e comunitárias. Mesmo sabendo que o turismo de massa não irá desparecer, o autor defende que o novo turismo se baseará em insights, inspiração, informação e envolvimento e menos no turismo massificado e sem identidade. Essa preocupação com os novos consumidores começa a aparecer em alguns empreendimentos, como no caso da Barraca Chega Mais, que realizou adequações em busca da sustentabilidade.

Ao longo do desenvolvimento desta pesquisa, outra transformação observada na fala dos prestadores de serviços turísticos de pequeno porte atuantes em Canoa Quebrada, e especialmente na Rua Dragão do Mar - rua principal -,é que há um aumento constante no valor dos imóveis e dos aluguéis, afastando algumas atividades econômicas que perderam a capacidade de se manterem nas áreas centrais. Deixando claro a presença de uma forte especulação imobiliária e o aumento do custo devida na localidade.

Em Canoa Quebrada, observa-se, exclusivamente na alta estação de fluxo turístico e em períodos de eventos específicos como Ano Novo e Carnaval, a formação de grandes congestionamentos, sendo difícil transitar no lugar e nas vias de acesso. A combinação de uma série de fatores, como maior procura pelo destino, bem como o fluxo de pessoas que apenas visitam o lugar, ocasiona esses congestionamentos. No entanto, são fatos isolados e, como a localidade possui apenas uma entrada/saída, é previsível que isso ocorra, nestes períodos. Criam-se aspectos determinantes na sazonalidade da atividade de turismo local.

Possivelmente o mercado espera que seja possível haver uma constante expansão das atividades produtivas. Contudo, em destinos turísticos dependentes de aspectos físicos e naturais, não se pode, ou não se deve cultivar essa premissa do capital, visto que os recursos são esgotáveis e precisam ser utilizados seguindo os princípios da sustentabilidade e os estudos de capacidade de carga. Afinal, trata-se de uma destinação turística com eminente fragilidade de seus recursos ambientais e paisagísticos. A vila de Canoa Quebrada localiza-se entre o mar, as dunas móveis e as falésias, e não dispõe de espaço físico para uma expansão contínua. 0 fluxo de turistas não pode ser estimulado através 
de ações de marketing, incansavelmente. Um exemplo desse tipo de estratégia, que já foi adotada pelo Governo do Estado do Ceará, foi o "Férias no Ceará": o evento trazia atrações nacionais para grandes shows em Canoa Quebrada, fazendo com que congestionamentos, aumento da geração de lixo e falta de água fossem apenas os mais evidentes impactos da estratégia adotada, colocando em risco a sustentabilidade local.

Observa-se, em Canoa Quebrada, uma segregação residencial, visto que as áreas litorâneas foram ocupadas pelas barracas de praia e meios de hospedagem e a população foi sendo levada para áreas periféricas, mais distantes da praia. Sobre esse fenômeno, Harvey (2012, p. 202) explica que "O domínio do espaço reflete o modo como indivíduos ou grupos poderosos dominam a organização e a produção do espaço mediante recursos legais ou extralegais [...]". Assim, ocorreu uma valorização das áreas litorâneas e da rua principal (espaço de domínio), ficando as áreas periféricas com uma infraestrutura inferior, sendo ocupadas pelos trabalhadores que residem na localidade. Todavia, esta é uma situação que se verifica em qualquer parte do mundo quando o empreendedorismo turístico surge associado a processos de massificação, sendo difícil travar os fenômenos de aumento de carga no território, por parte dos turistas.

As atividades econômicas que impulsionaram o desenvolvimento econômico da sede de Aracati entraram em estagnação, havendo uma inércia; as edificações são tombadas, mantém-se um simbolismo, mas deixa-se de obedecer à racionalidade econômica. A especulação eminente da vila desenvolve dissociando da reprodução de capital na sede. Reforça-se a condição definida por Carlos (1996), em que se pode observar que "[...] o espaço fragmenta-se através de formas de apropriação para o trabalho, para o lazer, para morar, para o consumo, etc. Desse modo, o espaço fragmenta-se em espaços separados, parcelas fixas, como consequência de uma atividade parcelada [...] (p. 85).”. No município de Aracati, essa fragmentação do espaço é percebida à medida que, na sede, estão concentradas as funções administrativas (órgãos públicos, bancos, correios), fiscais, políticas (Câmara Municipal e Prefeitura), de gestão (Secretaria Municipal de Turismo, Sebrae, instituições de capacitação) e de cultura. Os fornecedores de insumos e mercadorias para os prestadores de serviços turísticos de Canoa, também estão em Aracati, enquanto, em Canoa Quebrada, está o locus de produção do turismo, o produto turístico com capacidade de atrair visitantes.

Outro aspecto marcante observado retrata que a praia de Canoa Quebrada, que oficialmente é um bairro da sede de Aracati, não significava lugar de lazer para a população residente no município, sendo destinada predominantemente para turistas, e as praias de Marjorlândia e Quixabá destinadas ao lazer da população local. Atualmente, já se percebe um grande número de jovens de Aracati nas festas noturnas realizadas em Canoa Quebrada, e também um aumento no fluxo de veículos particulares e vans entre Aracati e Canoa Quebrada nas noites dos finais de semana. Situações que retratam contrastes socioculturais marcantes, provavelmente gerando outros conflitos que não foram tratados nesta pesquisa.

As materialidades, criadas pelo homem, facilitaram o acesso à praia de Canoa Quebrada: a rodovia que liga Fortaleza à Aracati/Canoa Quebrada teve sua malha duplicada. $O$ início das operações do aeroporto regional de Aracati também acarretará mudanças nesses espaços fragmentados, que só poderão ser analisadas 
após a geração de um fluxo. Sabe-se que os espaços se desenvolvem em intervalos cada vez mais curtos e progressivos. Devido a isso, o cenário desses anos de pesquisa será rapidamente transformado.

Geertz (1989) explica que "[...] a humanidade é tão variada em sua essência como em sua expressão (p. 49).”. À medida que se estuda a rede, a sociedade de inserção do homem "retira-se camada após camada", chegando-se sempre a camadas distintas. Apesar do contexto apresentar singularidades, também possui universalidades, no sentido de ter conteúdo semelhante ao de outros. A singularidade é observada quando se traça a evolução histórica do espaço, quando aspectos específicos da cultura assumiram suas forças e modelaram o desenvolvimento do lugar; enquanto a universalidade é identificada quando se trata de questões relacionadas aos avanços tecnológicos, sendo esse processo semelhante ao experimentado em outras destinações turísticas. Essa necessidade da sociedade urgente em se inserir na rede mundial parece se apresentar como universal.

As porções, ou partes do território, não são mais autônomas, independentes, intencionais e isoladas, possuindo, em menor ou maior grau, interdependências. Vive-se em um planeta "mundializado"/globalizado (Sassen, 2020) . Nele, ordens, determinações, crises, sucessos e insucessos diversos são definidos e atribuídos planetariamente.

Geertz (1989) afirma que "[...] pode ser que nas particularidades culturais dos povos - nas suas esquisitices - sejam encontradas algumas das revelações mais instrutivas sobre o que é ser genericamente humano (p. 55).”. Acredita-se que essas particularidades formam a identidade de um lugar, bem como as histórias dos antepassados de uma sociedade, demonstrando traços dessa identidade. A população da cidade de Aracati, por exemplo, acostumou-se a esperar o vento Aracati nas calçadas de suas casas, sendo estas transformadas em verdadeiras amálgamas para redes sociais, onde as pessoas compartilham e curtem os acontecimentos da vida cotidiana. Essa tradição se estende a todo o Vale do Jaguaribe, uma vez que a brisa litorânea entra pelo leito do rio e lembra o sertão de suas relações com o litoral.

De acordo com Aguilar, Muñoz \& Ortiz (2015):

En el proceso de modernización propio del modo de producción capitalista motiva los cambios en el paisaje con la finalidad de transformarse y adaptar nuevas formas de socialización, entre las cuales, el turismo presenta una diversidad de cambios a lo largo de su evolución hasta llegar al uso de la tecnología, es decir, que está en constante cambio dependiendo casi siempre entre otros factores de las condiciones políticas y económicas (p. 5).

Em Aracati/Canoa Quebrada, não se percebe a existência de grandes conglomerados ou fusões de empresas, talvez pelo porte do destino, mas se percebe a estruturação de uma rede de prestadores de serviços, muitos da própria comunidade, como também se observa um número significativo de empreendedores de outros estados brasileiros e de outros países. Um fato chamou nossa atenção: o papel de protagonismo desempenhado por esses investidores de fora da vila, visto que eles se fazem presentes na maioria das discussões sobre o destino turístico de ação, em fóruns. Conselhos e associações. 
Ferrara (2000) ressalta a existência de transformações decorrentes da introdução da eletrônica no cotidiano. Seriam essas: outros modos de trabalho, outro tempo livre, outras relações interpessoais e outras formas de socialização. EmAracati/Canoa Quebrada, já se percebe outro modo de trabalho, principalmente na forma em que o destino turístico é comercializado: no passado, as agências montavam pacotes e os comercializavam, sendo que, atualmente, os prestadores de serviços turísticos formais e informais, já inseridos na rede, podem vender o seu serviço para consumidores de qualquer lugar do globo, assim como podem comprar produtos de fornecedores de outras regiões ou países. As relações interpessoais também estão mais fluídas, pois as pessoas se conhecem virtualmente nas redes e escolhem pontos de conexão, e as ideias e avanços também são mais facilmente socializados. A exemplo disso, tem-se o Airbnb, que chegou ao Brasil durante a Copa do Mundo de 2014 e hoje já oferta acomodações em residências de Canoa Quebrada.

Sabe-se, através das leituras de Dollfus (1991), que todo espaço

[...] é também um espaço diferenciado. Por sua localização e pelo jogo de combinações que preside a sua evolução, todo elemento do espaço e toda paisagem constituem fenômenos únicos que jamais podem ser encontrados exatamente iguais em outros locais ou em outros momentos (p. 9).

O turismo, um típico fenômeno da contemporaneidade se apropria dos recursos naturais e das especificidades dos lugares e estimula diferentes formas de uso desse espaço (Kunz \& César, 2014). A estruturação da rede de serviços turísticos de Aracati acarretou inúmeros efeitos no espaço geográfico e na sociedade. Esses efeitos são observados tanto na sede do município de Aracati, que representa um espaço arcaico de tempos lentos, como na Praia de Canoa Quebrada, que vive até certo ponto em tempos relativamente rápidos.

\section{CONSIDERAÇÕES FINAIS}

Esta pesquisa pretendia analisar os efeitos sócio-espaciais da estruturação da rede de serviços turísticos de Aracati/ Canoa Quebrada no Ceará. Para tanto, realizou-se pesquisa direta com os atores da rede de serviços turísticos, bem como observação direta do fenômeno.

Os principais aspectos observados na estruturação da rede dizem respeito ao seu processo de surgimento e estruturação. 0 surgimento espontâneo, através do estímulo de fatores e agentes exógenos, fez com que fosse elaborado um planejamento prévio para o desenvolvimento da atividade turística. 0 poder público e os órgãos setoriais de turismo só começaram a atuar no local quase duas décadas depois do início do fluxo de visitantes, quando a iniciativa privada e o terceiro setor já desempenhavam seus papéis. Assim, questões como a identidade e a imagem do destino, bem como a sustentabilidade, parecem clamar por reflexões sérias e sistematizadas, que envolvam a participação da população local. Percebe-se claramente o foco em ações de marketing e de divulgação, enquanto ações de qualificação e de estruturação do destino ainda são raras, comprometendo a qualidade dos serviços prestados e da imagem. 
a formação de núcleos de estudos sobre a atividade turística nas instituições de ensino presentes no município as discussões sobre efeitos sociais, culturais, ambientais e políticos sejam cada vez mais frequentes e que possam utilizar os estudos pré-existentes, a exemplo deste, como base para novas sinceras reflexões sobre o turismo em Aracati.

\section{REFERÊNCIAS}

Aguilar, A. A., Muñoz, A. P., \& Ortiz, J. S. (2015). El turismo y la transformación del paisaje natural. Nóesis - Revista de Ciencias Sociales y Humanidades, 24(47), 19-29. www. redalyc.org/pdf/859/85939868002.pdf

Augé, M. (1994). Não-lugares. Campinas-SP: Papirus.

Baudrillard, J. (1970). La société de consommation. Paris: Gallimard.

Borzacchiello, J.; Cavalcante, T. C.; \& Dantas, E. W. C. (2007). Ceará: um novo olhar geográfico. 2. ed. Fortaleza: Democrito Rocha.

Boullón, R. C. (2002). Planejamento de espaço turístico. Bauru: Edusc, (Coleção Turis).

Brazo, D. A. \& Fonseca Filho, A. S. (2018). Turismo Otaku: imaginário e motivações de uma nova tipologia. Revista Turismo em Análise. 29 (2), 273-291. http://dx.doi.org/ 10.11606/issn.1984-4867.v29i2p273-291

Carlos, A. F. A. (1996). Ensaios da geografia contemporânea Milton Santos: obra revisada. São Paulo: Editora Hucitec.

Castells, M. (1999). A sociedade em rede. 6. ed. São Paulo: Paz e Terra.

Ceará. (2010). Conselho Estadual do Turismo. 07. Jun. 2015, www.ceara. gov.br

CNUMAD - Comissão Mundial para o Meio Ambiente e Desenvolvimento. (1991). Nosso futuro comum. Rio de Janeiro: Fundação Getúlio Vargas.

Corrêa, R. L. (2001). Trajetórias geográficas. 2. ed. Rio de Janeiro: Bertrand.

Costa, E. B. da. (2015). Cidades da patrimonialização global: simultaneidade totalidade urbana - totalidade-mundo. São Paulo: Fapesp.

Costa. C. \& Santos, N. (2018). A paisagem enquanto produto turístico e património natural e cultural. 0 caso da Serra da Estrela. Cadernos de Geografia. 38, Coimbra, 23-41. https://doi.org/10.14195/0871-1623_38_4

Diógenes, B. H. N.; \& Duarte Júnior, R. (2006). Guia de bens tombados do Ceará. Fortaleza: Secretaria de Cultura. (Coleção Nossa Cultura. Série Documentos).

Diógenes, C. M. (2016). Estruturação e dinâmica da rede de serviços turísticos em Aracati/Canoa Quebrada-CE: 1970-2015. (Tese de Doutorado). Universidade Estadual Paulista Júlio de Mesquita Filho, Rio Claro-SP.

Dollfus, O. (1991). 0 espaço geográfico. Trad.: Heloysa de Lima Dantas. Rio de Janeiro: Bertrand.

Esmeraldo, L. R. A. (2002). Jangadeiros e pescadores: os dilemas do turismo em Canoa Quebrada, Aracati, Ceará. Fortaleza: Senac. (Turismo Cearense).

Fávero, I. (2012). A rede do turismo em ação: o caso de Bento Gonçalves e da Região Uva e Vinho (Serra Gaúcha). In: Beni, M. C. Turismo: planejamento estratégico e capacidade de gestão: desenvolvimento regional, rede de produção e clusters. São Paulo: Manole.

Ferrara, L. D. (2000). Os significados urbanos. São Paulo: Universidade de São Paulo.

Fratucci, A. C. (2009). Refletindo sobre a gestão dos espaços turísticos: perspectivas para as redes regionais de turismo. Revista Turismo em Análise. 20(3), 391-408. 
Geertz, C. (1989). A interpretação das culturas. Rio de Janeiro: Guanabara Koogan.

Haesbaert, R. (1994). 0 mito da desterritorialização e as "regiões-rede". In Anais do V Congresso Brasileiro de Geografia, Curitiba, PR, 206-214.

Haesbaert, R. (1997). Des-territorialização e Identidade: a rede "gaúcha" no Nordeste. Niterói: EdUFF.

Haesbaert, R. (2001a). Da desterritorialização à multiterritorialidade. In Anais do IX Encontro Nacional da ANPUR, Rio de Janeiro. https://www.seer.ufrgs.br/bgg/article/ view/38739/26249

Haesbaert, R. (2001b). Le mythe de la déterritorialisation. Géographies et Cultures, 40, Paris: L'Harmattan. https://doi.org/10.4000/gc.13571

Haesbaert, R. (2002a). A multiterritorialidade do mundo e o exemplo da Al Qaeda. São Paulo: Associação dos Geógrafos Brasileiros.

Haesbaert, R. (2002b). Fim dos territórios ou novas territorialidades? In: Lopes, L. \& Bastos, L. (org.) Identidades: recortes multi e interdisciplinares. Campinas: Mercado de Letras.

Haesbaert, R. (2004). 0 mito da desterritorialização: do "fim dos territórios" à multiterritorialidade. Rio de Janeiro: Bertrand Brasil.

Haesbaert, R. \& Limonad, E. (1999). 0 território em tempos de globalização. Geo Uerj. 5(7), 7-19. www.e-publicacoes.uerj.br/index.php/geouerj/article/view/49049/32762

Harvey, D. (2012). Condição pós-moderna: uma pesquisa sobre as origens da mudança cultural. 22. ed. São Paulo: Loyola.

Kunz, J. \& César, P.A. B. (dez. 2014). Uma análise das possibilidades e limitações do turismo no espaço urbano de Caxias do Sul-RS, Brasil. Revista Hospitalidade. V.11 (2). https:// www.revhosp.org/hospitalidade/article/view/543/574

Lipovetsky, G. (2007). A felicidade paradoxal: ensaio sobre a sociedade de hiperconsumo. São Paulo: Companhia das Letras.

Menezes, M. O. T. D., Araújo, F. S. D., \& Romero, R. E. (2010). 0 sistema de conservação biológica do estado do Ceará: diagnóstico e recomendações. REDE - Revista eletrônica do PRODEMA. 5(2), 7-31. www.revistarede.ufc.br/rede/article/view/71

Middleton, V. T., \& Clarke, J. (2002). Marketing de turismo: teoria \& prática. Elsevier.

Molina, S. (2003). 0 pós-turismo. São Paulo: Aleph.

Rodrigues, A. B. (2003). Ecoturismo no Brasil: possibilidades e limites. São Paulo: Contexto.

Santos, M. (2014). A natureza do espaço: técnica e tempo, razão e emoção. 4. ed. São Paulo: Edusp

Sassen, S. (2010). Sociologia da globalização. Porto Alegre: Artmed.

Urry, J. (2001). O Olhar do turista. São Paulo: Studio Nobel.

Vale, A. F. C. (2015). Canoa: verso rabiscado na areia. Brasil.

Recebido em: $18 / 01 / 2020$

Aprovado em: 12/12/2020

\section{CONTRIBUIÇõES}

conceição Malveira Diógenes: Definição do problema de pesquisa e objetivos, desenvolvimento da proposição teórica, realização da revisão bibliográfica e fundamentação teórica, escolha dos procedimentos metodológicos, coleta e análise de dados, elaboração de tabelas, gráficos e figuras, redação e adequação do manuscrito às normas da RTA. 
Pedro de Alcântara Bittencourt César: Desenvolvimento da proposição teórica, realização da revisão bibliográfica e fundamentação teórica, escolha dos procedimentos metodológicos, elaboração de tabelas, gráficos e figuras, revisão crítica, redação e adequação do manuscrito às normas da RTA.

Norberto Nuno Pinto dos Santos: Definição do problema de pesquisa e objetivos, desenvolvimento da proposição teórica, realização da revisão bibliográfica e fundamentação teórica, escolha dos procedimentos metodológicos, redação e adequação do manuscrito às normas da RTA. 
O Plano de Manejo, essencial para o desenvolvimento sustentável da atividade turística da área de preservação de Canoa Quebrada foi concluído quase que no mesmo período deste trabalho; assim, não se pode observar os impactos de tal plano. Espera-se que a implantação desse Plano gere outros efeitos, bem como regulamente e ordene a ocupação das áreas da Vila, entretanto, ainda aguarda aprovação.

Muitos foram os impactos sócio-espaciais, causados pelo desenvolvimento do fenômeno turístico, observados em Canoa Quebrada, conforme demonstrou-se ao longo deste artigo. Além disso, a estruturação de uma rede de serviços turísticos em Aracati/Canoa Quebrada alavancou um relativo crescimento socioeconômico. Fala-se em relativo pois entende-se que a rede de turismo local ainda não possui todos os elementos das redes globais de turismo.

Os principais impactos observados no espaço geográfico, pensado aqui como espaço social, a partir da estruturação da rede de serviços turísticos de Canoa Quebrada / Aracati foram: criação de uma interdependência entre Canoa Quebrada e Aracati, onde a lógica da centralidade foi invertida, hierarquia; maior interação espacial; ocupação da área de praia por novas práticas litorâneas, mas sem haver um completo abandono das atividades tradicionais que ainda resistem; aumento no valor dos imóveis e dos aluguéis em áreas de maior fluxo turístico; aumento da população residente e da população flutuante; aumento de fluxo da mão de obra trabalhadora da atividade turística entre Aracati e Canoa Quebrada, forte presença de estrangeiros e de brasileiros de outros estados da federação empreendendo no destino; ocupação de ecossistemas frágeis; aglomeração dos prestadores de serviços turísticos; melhoria nas condições de acessibilidade do destino turístico: e segregação dos espaços entre turistas e residentes (espaço do turista e espaço do turismo).

Inicialmente os hóspedes ficavam hospedados em casas de pescadores, compartilhavam com eles suas casas, refeições e tradições, aproximando-se em alguns aspectos do turismo de base comunitária. 0 crescimento do destino, a especulação imobiliária e o afastamento/ expulsão do homem do mar de seu local de trabalho e de vivência fez surgir pequenas acomodações, posteriormente pousada e hotéis de médio porte. Atualmente observa-se um retorno às acomodações em casas de família através de plataformas como o Airbnb, assim como o fechamento de hotéis para que sejam administrados nos moldes da plataforma.

Dessa forma, observa-se que o espaço social do destino turístico estudado criou novas teias de relações. Essas relações atualmente extrapolam a escala local, ampliam-se e conectam-se com a escala global. Ao fazer uma analogia com as redes de pesca dos pescadores tracionais da região e as telas das rendas de labirinto, percebe-se que em Canoa Quebrada formou-se uma trama de relações em torno da atividade turística. No entanto, para que essa rede obtenha estabilidade, para que os fluxos fluam, é necessário o surgimento de novos nós e principalmente que os atores locais assumam o protagonismo dessa atividade.

Este artigo não pretende esgotar as discussões sobre os efeitos sócio-espaciais, uma vez que a dinâmica da atividade turística faz com que o destino esteja em constante transformação. Este trabalho, no entanto, representa uma das possibilidades de investigação deste recorte territorial no espaço temporal estudado. Aponta uma grande variedade de enfoques possíveis e necessários para reflexões sobre a atividade turística em Aracati/Canoa Quebrada. Espera-se que com 